\title{
The Implementation of Collaborative Technique in Teaching Writing to Enhance Students' Skill in Writing English Text
}

\author{
Ratih Inayah \\ Dosen IKIP Siliwangi \\ Jalan Terusan Jend. Sudirman, Baros, Kota Cimahi \\ Sur-el: ratih.inayah@gmail.com
}

\begin{abstract}
This study aims to seek insight into the use of Collaborative techniques in enhancing students' interest in writing English and analyzing students' character development in writing skills by applying Collaborative techniques. It employs qualitative descriptive research where the primary data analyzed is the development of students' writing interest and skill during the time of the implementation of the Collaborative Technique. In addition, as secondary data, the analyses of interview and classroom observations were tabulated as supporting primary data. Participants selected by using the Purposive Participant technique. A total of 60 regular students of the 2018 English Education Study Program at one of the private universities in Bandung were involved. The results of the study showed that collaborative technique is successful to increase students' interest in writing English and also help them to develop their own writing skill form before the implementation, during, and after the implementation of Collaborative technique. Thus it can be concluded that collaborative technique affects the process of writing as an individual and group. By doing collaborative techniques in writing English, students tend to be an enthusiast to make a better writing text in English.
\end{abstract}

Keywords: Collaborative Technique, Writing, Character development

\begin{abstract}
Abstrak: Penelitian ini bertujuan untuk mencari wawasan tentang penggunaan teknik Kolaboratif dalam meningkatkan minat siswa dalam menulis bahasa Inggris dan menganalisis pengembangan karakter siswa dalam keterampilan menulis dengan menerapkan teknik Kolaboratif. Penelitian ini menggunakan penelitian deskriptif kualitatif di mana data primer yang dianalisis adalah pengembangan minat dan keterampilan menulis siswa selama masa penerapan Teknik Kolaborasi. Selain itu, sebagai data sekunder, analisis wawancara dan observasi kelas ditabulasi sebagai data primer pendukung. Peserta dipilih dengan menggunakan teknik Partisipan Purposive. Sebanyak 60 mahasiswa reguler dari Program Studi Pendidikan Bahasa Inggris 2018 di salah satu universitas swasta di Bandung terlibat. Hasil penelitian menunjukkan bahwa teknik kolaborasi berhasil meningkatkan minat siswa dalam menulis bahasa Inggris dan juga membantu mereka untuk mengembangkan bentuk keterampilan menulis mereka sendiri sebelum pelaksanaan, selama, dan setelah penerapan teknik Kolaboratif. Dengan demikian dapat disimpulkan bahwa teknik kolaboratif mempengaruhi proses penulisan sebagai individu dan kelompok. Dengan melakukan teknik kolaboratif dalam menulis bahasa Inggris, siswa cenderung menjadi penggemar untuk membuat teks tulisan yang lebih baik dalam bahasa Inggris.
\end{abstract}

Kata Kunci: Teknik kolaboratif, Menulis, Pengembangan karakter

\section{INTRODUCTION}

As one of the basic skills of language, we know that writing is considered as a productive skill which needs so much effort and experience to do it well. Writing is not only pouring the words into paper but also needs so much knowledge and experience to make a meaningful writing. Writing English in this case, is not something simple since English is not our mother tongue. We need much time and effort to be able to write like a native. Moreover, we 
seldom find a supportive environment that push us to write in an enjoyable moments to write what is interesting and important for us. Musthafa (2008) states that writing needs so much persistent in pouring our ideas to make it understandable for the people who read it.

Today, everyone writes in his daily life, whether it is writing an informal text for SMS, writing an informal text to chat in any social media, and even so many people write an electronic mail in professional life. For person who writes the texts, probably they feel that they have done their best in writing performance. However, related to academic life, it is s not always a simple experience since the reality that it always seems to be so hard to write academic writing. Writing is not always a simple experience. As we know, it is related to coherence, cohesion, and background knowledge of the writer himself (Halliday and Hasan, 1976). In this study, the writer tried to invite students to open up their mind, for writing. Brown (2002) stated that writing is considered as the hardest skill to achieve naturally. The collaborative writing here, which means Collaborative technique is the technique that makes students not only pay attention to their writing skill but also to others writing skill (Alwasilah, 2002), because they have to work together to evaluate the text and students also should give input to someone else's writing.

Every time a student try to write an English text especially narrative text, he must be full of consideration about the vocabulary, the tenses, the plot of the story, the coherence of the story, and the other factors that make it seems to be so complicated. In collaborative writing, the difficulties are shared and discussed together to meet the solutions so that it will be easier for students to learn how to write an English text with friends happily.

In this modern life, there are many ways to make our writing published worldwide; we can upload our writing through blog, or special website that we make. The advantage of publishing your writing are first you can share your knowledge and experience with people in all the world, you can find new idea to make friends and enrich your understanding of international world. Beside the advantages, there must be some disadvantages that you can find that, the things that you cannot avoid are other people opinion toward your writing, their response toward the content of your writing, and then probably it can bring you up and down feelings. But even a professional or popular writer, they almost often got critics from some people, from their reviewer, even from their haters. Somehow writing process must go on, even though you are not perfect writer, even though you are still trying to make a good writing, you still have to carry on your writing process until finish.

If students are trying to be a good writer, so they must have sense of belonging to writing, but he also has to be able to feel the feeling of the reader, otherwise he will be considered as a selfish writer. Every time one writes, he has to realize that maybe his writing can inspire others, so being careful about something that is written is very important. For beginner writer, the implementation of collaborative writing can be 
implemented through writing text such as narrative and descriptive text. Students then have experience of being a proofreader, but you will also know how if your writing is evaluated by other people, here you are going to sharp your sense of belonging.

When somebody writes alone, by himself, he will think that everything is good, his writing is understandable by himself, and then he considers people will straightly understand it. According to Emilia (2008) being a professional or popular writer needs a proof reader; proofreader can act as a reviewer who can give evaluation and input to the writing objectively without any offense. Moreover if the writing is produced by students who are still learn how to be a good writer, how to put cohesion and coherence in the writing process. This case is very often happened in the classroom of beginner writer who usually think that writing is a simple process, and the reality is not.

From the above description of this study aims to answer the research question:

1. How does Collaborative technique affect students to be more enthusiasts in writing English?

\section{METHODOLOGY}

This research applied qualitative method, since the researcher considered it is the most appropriate method to find and pay attention to the phenomena that writing English is considered as difficult to be practiced by some students in University. In this research, the researcher also has a role as a teacher. The process can be described as ; the students have to write alone first, but after that they have to work with partner and they are asked to correct each other work. It is aimed to produce good writing performance. The qualitative method was used in this study; the researcher took the data from classroom observation, interview, and questionnaire. The process of Collaborative writing was not easy for the beginning because the students did this for the very first time, they who never expose their writing performance think it as difficulties and they do not want to looked fool in front of their friend. However, the researcher keeps remembering the students that to help others means that the students will be also helped by others. However, they eventually realize that writing can be so much fun and it is not a selfish skill. So, this is the opportunity to make writing more fun and interesting for students. According to Harmer (2004) A consideration of the writing process, and how speaking and writing are related to each other especially in a world of changing communication media- is not only of academic interest. Many traditional approaches, for example, failed to incorporate the kinds of insight into the writing process. Harmer (2004) also stated that for many years the teaching of writing focused on the written product rather than on the writing process. In other words, the student's attention was directed to the rather than the how of text construction. General writing skills allow comprehension across different subject matters, specific content knowledge allows the construction of a deeper level of 
understanding within a subject matter, and background knowledge enables learners to relate what is read to what they already know (Leki, 1998).The students were divided into some groups, after that they are asked to write the text, narrative and descriptive. It is a qualitative descriptive research where the primary data analyzed is the development of students' writing interest and skill before, during, and after the implementation of collaborative writing technique (Fraenkel and Wallen, 2008) They do it for themselves for the first time that they have to write narrative text. First, they will read the story from international book. Story for Reproduction published by Oxford. They have to choose the best story, only write five stories from the book, after that they have to retell the story that they like the most. Oxford Story for Reproduction is used in this study because the stories in the book are not only fun and entertaining but also full of moral message even though it is extended indirectly. The students can laugh when reading the stories, but in the same time they can think about the moral value in the society (Thomson, 1999), so that it gives a message that as a human being we cannot depend upon condition, we must work the best for ourselves and for the people that we respect. The characteristic of the students can be seen by doing the research, whether they help their friends sincerely or not.

According to Williams (1995) when you want to write a narrative text, you should have an idea in your brain, before pouring your idea onto paper, you must make sure that your writing consists of understandable vocabularies, clear intention, and meaningful. Somehow, this is the challenge for the writer to pour what it is in your mind and how to make people understand what you want to extend and explain to them. Written communication is not as easy as what people think, because the readers often do not have an opportunity to meet the writers directly. Therefore, all you have to do as a writer, you must be able to feel the feelings of your reader, it is not simple, but you still have to find way to make it comes true.

Students almost always do writing all alone, without proof reader, but the teacher (Brown, 2002). In this study, they have to be proof reader for their friends, even though it is not simple for beginners to be proof reader, but they have to try this. In collaborative writing, it is proved that write, share, and revise are able to give students opportunity to be a good writer by trying to feel what is in reader's mind. It is expected that the students will not be a selfish writer but they will have empathize to the readers.

Very often, we find a text that is so hard to understand. Probably we asked what was wrong with the writer or what was wrong with us as the reader. The text can be decided as a good text if the reader can understand it and can take lesson from it. Somehow, as a writer maybe not all of the writers are having sense of the sense of reader.

The process of the study will be explained clearly here. Firstly, the researcher takes a class, she makes an observation to gain the information about students' writing ability and their performance in writing. The second, the researcher give the same assignments to students 
to write a descriptive text with the same theme. After that, they try to make it as good as possible because they want to share it with their friend, they are given time to write what is interesting and important to them. After that, they will check it again, they check their own writing about coherence, cohesion, and vocabulary.

For this assignment, they are given time to think what is the main idea of their writing. They will think that it will be very meaningful to think carefully what is interesting and important for them, as a teacher, the researcher give the clearest instruction that all students should be honest in pouring their thought in their writing. For instance, the students will show their honesty about their idea in writing descriptive text especially when they have to describe themselves in proper way. In writing descriptive text, they have to master vocabulary and adjective to make the sentence meaningful. Here, this is a good opportunity for them to add and enhance their vocabulary mastery and their grammar to make the sentences understandable. In this moment, teacher can give opportunity to students to make all the students dig their best performance, they must do their best and are supported to struggle with themselves and try to make it as good as they can. Students are given time during sixty minutes to do the assignment in the classroom. The sixty minutes is considered as an enough time to do the collaborative writing.

\section{RESULT}

This research already answers the research questions by data. One way of encouraging drafting, reflection, and revision is to have students involved in collaborative writing. A pair of group of students working together on a piece of writing can respond to each other's ideas, making suggestions for changes, and so contributing to the success of the finished product.

The way we respond to our students' writing, in order for a process- writing approach to work well, some teaches may need to rethink the way in which they react to their students' work. In place of making corrections to a finished version, they will need, at times, to respond to a work-in-progress. This may involve talking with individual students about a first, second, third, or fourth draft, while other members of the group are working on their own. Alternatively, teachers can read through a draft and then make written suggestions about how the text could be reordered. Such reformulation will be beneficial to the student who compares their version with their teachers'. So, it is not just teachers who can respond to students' writing. It is often useful to have students look at work done by their colleagues and respond in their own way. Such peer response may provide a welcome alternative to the teacher's feedback, as well as offering a fresh perspective on the writing.

Process writing is a way of looking at what people do when they compose written text (Nunan, 2003). Nevertheless, process writing 
may not be the answer in every learning situation. Over- emphasis on process elements may lead us into the process trap. Process writing is not an easy an easy option for students or teachers. It also seems clear that students of general English need to be presented with a range of writing tasks, including some of those that are more speaking-like.

Based on interview and observation, it is also reveals that students' are still struggle with writing materials. This implies that the students were still needed extra care from teachers. Thus it can be seen that collaborative technique affects the process of writing as an individual and group. By doing collaborative techniques students tend to be more open minded and lessen selfish feeling and ego by trying to help each other to make a better writing form. Eventually, writing English can be considered as a happy experience and unselfish activity.

The result of this study was relevant with the previous studies conducted by Talib and Cheung (2017), Soraya (2016), and Deveci (2018) in which the result of their study showed that by using Collaborative technique in teaching writing can give students opportunities to use language with their own way and style. Teacher also gives students challenge to be successful to communicate with others. This is somehow can bring the teaching and learning become more meaningful than before, and then the students also get so many advantages. The advantages are; first, they can get more information about the steps to write a text that they need to know. Second they can increase their writing skill because they have to write in appropriate way, by using collaborative technique. Third they can group a concept through write, share, and revise. It is very essential to know that writing narrative texts can make the students increase their vocabulary and at the same time they can increase their knowledge skill.

\section{CONCLUSION}

The process of collaborative writing was proved in helping teacher to empower students' writing skill and develop the ability of students to work with others so that they can lessen their selfish behavior. Students can also develop their own motivation in writing together with their frend, help each other, and having both sense of being a reader and writer. Writing is considered to be a happy experience after using this collaborative writing. This technique also develop students' imagination in writing narrative text without feeling doubt or afraid of other people opinion and suggestion about their writing. The experience of using collaborative technique is become very meaningful for students and teacher. This collaborative technique is considered interesting because English is not our native language, but as a teacher it is our duty to support our students to make English and writing in English activity as a part of their daily lives. 


\section{REFERENCES}

Alwasilah, A. Chaedar. (2002). Pokoknya Kualitatif: Dasar-Dasar Merancang dan Melakukan Penelitian Kualitatif. Jakarta: Pustaka Jaya.

Brown, H. Douglas. (2002). Teaching by Principles: An Interactive Approach to Language Peadagogy. Second Edition. White Plains, NY: Pearson Education.

Brown, H.Douglas. (2002). Strategies for success: A Practical Guide to Learning English. White Plains, NY: Pearson Education.

Deveci, Tanju (2018). Student Perceptions on Collaborative Writing in a Projectbased Course. Universal Journal of Educational Research 6(4): 721-732, 2018

Fraenkel, J. R., dan Wallen, N. (2008). How to Design and Evaluate Research in Education. New York:

McGraw-Hill.

Halliday, M.A.K and Hasan, R (1976). Cohesion in English. London: Longman.

Harmer, Jeremy. (2004). How to teach writing. Edinburgh: Pearson Education Limited.

Leki, I. (1988) Academic Writing Exploring Processes and Strategies ( $2^{\text {nd }}$ edn). Cambridge: CUP

Musthafa, B. 2008. Teaching English to Young Learners: Principles and Techniques . Bandung. UPI Press.

Nunan, D. (2003). Practice English Language Teaching. New York: Mc Graw-Hill.
Soraya, K. (2016). The Effectiveness of Collaborative Writing Strategy (CWS) in Writing Lesson Regarded to The Students' Creativity. Lingua Cultura, $10(2)$. 63-67.

Talib, T \& Cheung, Y.L(2017) Collaborative Writing in Classroom Instruction: A Synthesis of Recent Research. The English Teacher, 46(2), 43 - 57.

Thomson, P. (ed.) (2000) Patterns and Perspectives: Insights into EAP Writing Practice, Reading: CALS, University of Reading.

Williams, K. (1995) Developing Writing 5 : Writing Essays. Oxford: The Oxford Centre for Staff. 